\title{
Violence Against Women in Evelina
}

\author{
Xin Huang \\ School of Foreign Languages and Literature \\ Wuhan University \\ Wuhan, China
}

\begin{abstract}
Evelina, the best-known novel of Frances Burney, tells a young rustic girl's entrance into London society. Burney portrays a vivid panorama of 18th-century London shrouded by appealing glamours and ubiquitous violence as well. This paper focuses on the physical, psychological and social violence the female characters encounter in the novel, aimed at exploring the fundamental reason for the terrible treatment from a feminist perspective. Women in 18th-century England were prone to be the target of physical violence mainly reflected in body harm and sexual abuse. Further, women also suffered from various forms of psychological violence in their daily life. It is argued by this paper that the violence against women is not an accidental result of individual pathology but the inevitable consequence of patriarchal definitions of gender roles.
\end{abstract}

Keywords—Evelina; violence; feminism; gender roles

\section{INTRODUCTION}

Frances Burney was a prestigious female novelist, satirist and playwright in 18th-century England. In 1778, Burney published her first novel Evelina anonymously which caused a sensation in British society soon after its publication. Mostly considered as a sentimental novel, Evelina tells a story of a 17-year-old rustic girl who is beautiful, pure, and innocent, gradually growing mature and sophisticated on her entrance to the secular society of London. The novel is told through different letters, most of which are written by Evelina to her guardian, the Reverend Mr. Villas. During her stay in London, Evelina has successive adventures and finally gains a perfect marriage with a distinguished nobleman through her continuous efforts in conforming to the social conventions. Regarded as a "paradigm of the Bildungsroman later prevailing in the Romantic and Victorian eras" [1], the novel also marks a milestone in the development of etiquette books aimed at moralizing the young ladies at that time.

As the most distinguished work of Frances Burney, Evelina has been so far mostly studied from the perspective of feminist criticism as it mainly concerns a woman's proper behavior and due responsibility. Some critics have succeeded in revealing the predicaments Evelina undergoes in the patriarchal society. In Defiant Women: the Growth of Feminism in Fanny Burney's Novels, Cutting asserts that Frances Burney is a feminist for she writes against the restrictions imposed on women in her novels [2]. Other common studies on Evelina include interpretations from the perspectives of formalist criticism, narrative criticism and historical-cultural criticism. This paper is aimed at exploring the violence inflicted on women in Evelina through the research approach of feminist criticism. Violence is classified therein and is argued to involve not only the sporadically physical and psychological traumas from men, but also the attempt of the entire society to restrict and tame women, a vulnerable social group. Therefore, the paper is original compared with most of the relevant research done before which only discussed the physical maltreatment against females without further analyzing the reasons behind it.

\section{Physical Violence Against Women}

\section{A. Body Harm}

Description on the physical violence against women prevails in the whole novel since the female characters are vulnerable in the relationship between the two sexes. In 18thcentury England, women were easily subject to assaults for their lower status both inside and outside the family. Traditional patriarchal ideology has deemed women as men's subordinates, making many women victims of physical violence mainly manifesting in body harm and sexual abuse.

In the novel, Captain Mirvan, the adversary of Madame Duval, always delights in teasing and torturing her to show his authority over women. Tightly obeyed by Mrs. Mirvan and Miss Mirvan in the family, Captain Mirvan resents being queried and challenged by any other woman, and thus he never hesitates to offend the exotic old lady who contradicts with him in many aspects. Courtesy seems to be void in Captain Mirvan's world since he rarely pays due respect to the elderly. After the Ranelagh party, the weather becomes quite terrible and their chariot breaks down halfway. Instead of showing sympathy to Madame Duval drenched in heavy rain, Captain Mirvan even takes the vacant seat in the hackney-coach and deserts her without any sense of guilt. Covered in mud, Madame Duval later shows up with great difficulty and embarrassment only to be heartily teased by Captain Mirvan. Finally, Madame Duval grows so enraged that she spits in Captain Mirvan's face, and he violently grabs her shoulders [3]. Madame Duval's miserable adventure well reflects that women tend to be the target of violence despite of their nationalities and ages.

Further irony lies in the gentlemen's bet on a race between two old women both of whom proved to be more 
than eighty years old. It sounds appalling that the so-called genteel men should indulge themselves in such inhumane activities. Just as Lord Orville commented, "the prevalence of fashion makes the greatest absurdities pass uncensored, and the mind naturally accommodates itself, even to the most ridiculous improprieties, if they occur frequently" [3]. Long immersed in the preposterous environment where abusing woman is acceptable, men will regard their improper behavior as justice. Seldom does the patriarchal society mourn for women's injuries which happen frequently in daily life.

\section{B. Sexual Abuse}

For a young innocent girl like Evelina, she is more likely to encounter sexual abuse after entering the society. Though always striving to maintain female delicacy, Evelina still suffers from the dandies' harassment. In 18th-century England, women were perceived as commodity and men kept hunting for new prey if the original one was not at issue. The ideology of objectifying women reinforced the ridiculous opinion that women bodies could be randomly distorted as they mainly served as tools of reproduction. According to Bartky, sexual objectification occurs when a woman's body parts are separated from her who falls as a physical object of male sexual desire [4]. Judging from the objectification theory, Evelina is probably an objectified woman since her hand contains metonymic significance [5]. In the novel, men pursuing Evelina all have strong desire to take possession of her hand, evidenced in Evelina's letter to Reverend Villars, revealing how her hand is repeatedly grabbed and kissed by the pursuers. Mr Lovel is the first one who offers to take Evelina's hand abruptly even without introducing himself. Another licentious man Sir Clement Willoughby always gives his high-flown compliments to Evelina despite the fact that he has been engaged to someone else. Every time he seizes the opportunity to stay with Evelina alone, he will try to grasp her hand and clutch it tightly. Mr Smith, one of the Branghtons' lodgers, is also constantly offering to take Evelina's hand but in vain. Grasping Evelina's hand actually means having body contact with her, which in the gentlemen's view hints the possibility of a closer relationship.

There seems to be a game of catch up between Evelina and her pursuers as she is continuously trying to escape from them. Steadfast in preserving her chastity and delicacy, Evelina refuses to stay with the repugnant fops for fear of being sullied. Chasity is the most important quality of a woman, and the loss of it before marriage can even destroy the rest of her life. The lack of a patriarchal identity makes Evelina the assumed public property easily exposed to men's disposal, and thus almost all the men except Lord Orville seduce Evelina without any intention of marrying her [6]. It is rather ironical that those seducers generally come from prestigious families with good birth and education. While attaching great importance to women's chastity, the hypocrites gain great pleasure and satisfaction from dallying with the innocent young girl. The pursuit of women is considered as a competition of being the most charming man in London's social circle, and hence, the fops spare no effort in flattering Eveliva not for sincere adoration but for satisfaction of vanity. Hostile to single woman, the expanded public sphere contributes to her risk of encountering sexual assault which is difficult for a woman to handle when she is alone.

\section{Pyschological Violence Against Women}

The living situation in 18th-century England is ruthless to women who have to put up with both physical and psychological violence, and the latter one occurs more frequently in social life since it is not restricted in a small familiar domain. Different to physical violence, psychological violence can cause permanent trauma that can be hardly cured with time passing. Severe psychological violence may even drive people mad by destroying their dignity and distorting their mentality. In the novel, Evelina suffers much psychological violence from verbal insults and discrimination for being an unknown child.

\section{A. Verbal Insults}

Varying from playful teasing to malicious humiliation, verbal offence is ubiquitous in social communication, and women are easy to become the target because of their deprived voice in public. In 18th-century England, one distinguished feature of decent manner for women was to keep silent when surrounded by a group of men. Especially for women like Evelina who just comes to city from village, it is wise of them to speak less in public so as not to make mistakes. Thus, the prohibition from speech has foiled their counterattack against men's insults. Unfortunately, most verbal insults are hard to recognize as well since they are subtle and insidious. Living in an unfriendly environment for a long time, women will be adapted to the insults, and thus they foster men's arrogance and violence. On the contrary, men can freely give their comments on women since they think they are obliged to correct women's manners, which strengthens their dominance over women.

Madam Duval is a comical but pathetic woman who suffers from incessant tortures both physically and psychologically. As a foreigner, she isn't treated with due respect and courtesy but with contempt and humiliation. In 18th-century society, youthful beauty was glamorized while aging women were viewed as female grotesque [7]. With "a fixed and most prejudiced hatred of whatever is not English" [3], Captain Mirvan seizes every opportunity to humiliate the poor old woman. In Madame Duval's debut, she is in desperate help, and all the bystanders would like to offer help except Captain Mirvan who scolds her for not being accompanied by an Englishman. Captain Mirvan taunts Madame Duval as Lady Howard's wash-woman and threatens to trip her out of the window. After claiming Evelina as her granddaughter, Madam Duval accompanies Evelina to many social activities where she encounters other gentlemen's mocking. In a ball, Evelina asks Mr. Smith if he would like to dance with Madam Duval again, Mr. Smith declines her proposal tactfully. The hypocritical gentleman just pleases Madam Duval to win Evelina's favor. 
Compared to Madame Duval, Evelina does not go through anything so torturous, yet she suffers much more psychological violence as an illegitimate child. Having just come to London, Evelina is completely immersed in the excitement and joy of entering the city, unaware of the potential hostility and danger towards herself. For lack of social etiquette, Evelina does not know how to behave herself properly, so she makes a lot of mistakes derided by the gentlemen. In her first ball, Evelina directly refuses the foppish man Mr. Lovel while soon accepting another man Lord Orville's invitation, which is considered inappropriate for a lady. Irritated by Evelina's unintentional fault, Mr. Lovel backbites her, revealing to Lord Orville that she must be of ill-breeding. The poor Evelina, at that time, begins to realize the harshness on her, and she is too disappointed at the city that she even wants to return to Howard Grove where she can at least stay far away from rumors. The insult sobers Evelina up from her fantasy of London - a metropolis that turns out to be much more filthy and violent.

\section{B. Emotional Isolation}

Emotional isolation is a significant source of distress and pain, and women tend to be disadvantaged due to their attachment to men in the patriarchal society. Women have limited access to express their emotions because they have to wear the mask of grace and nobility when communicating with others. In the novel, the protagonist Evelina is an exception whose innocence appears incompatible to her surroundings. Evelina has been raised in isolation, almost completely ignorant about the nature of the world since she is confined in Berry Hill until her seventeenth birthday [8]. Evelina's mother used to be Sir John Belmont's maid and rashly married him, however, she was soon abandoned by Sir John Belmont for being pregnant. Tragically, Evelina's mother dies giving birth to Evelina, leaving Evelina an orphan who is later adopted by the Reverend Villars. To prevent Evelina from suffering the same kind of fate as her mother, Villars strives to isolate Evelina from the outside world and danger. Hence, the rustic girl has no idea of what the urban life is like, taking it for granted that the people there are equally simple and friendly.

Having been mocked and despised by men with higher ranks, Evelina suddenly realizes that her longing for London is just fantasy. Afraid to be derided again, Evelina is stuck in a passive position not to reveal her emotions in public. For example, after the ridotto at Ranelagh, Evelina is inexpressibly concerned that Lord Orville will think her bold or impertinent. As Susan Staves argues, "assured safety lies only in obscurity and absolute punctiliousness; merely to frequent public places is to be exposed to risk" [9]. Rigid restrictions force women to hide their emotions that may violate the taboos. As a result, women prefer to stay in a comfort zone which separates them from the men who can express their emotions arbitrarily. On the contrary, woman have to constantly suppress their genuine emotions to evade from danger. Wary of showing favor to men, girls like Evelina must restrain their feelings or they may be considered licentious. The emotional isolation deprives women of their limited psychological space, forming a vicious circle that women have to suffer long-term spiritual pains.

\section{Social Violence Against Women}

Compared to physical and psychological violence, social violence do not directly cause harm to women but it penetrates into every aspect of $18^{\text {th }}$-century social life. The depiction of 18th-century manners "shows them up as restrictive and threatening elements ineffectual in restraining the transgressions of the power, the cynical, and the vulgar" [5]. It seems ridiculous that the manners of the time capture women as the prisoners enduring multifarious restrictions and imperceptible domestication instead of protecting them from unwanted insolence, abuse and violence.

\section{A. Conventional Restrictions}

Conforming to social conventions is an everlasting subject in human society, and women in 18th-century England are particularly the compliers with such rules. Those who transgress the conventional restrictions will be regarded as heretics, likely to get severe punishment. The patriarchal society has framed a set of rigid restrictions euphemistically described as handbook of proper manners helping women lead a better life. According to the gender roles of the time, women are expected to be gentle, modest, and submissive. In one of the letters from Mr. Villars to Evelina, he writes "Remember, my dear Evelina, nothing is so delicate as the reputation of a woman; it is at once the most beautiful and most brittle of all human things" [3]. To maintain the fragile characteristic, women do not stop transforming themselves until they meet the standard of "a qualified woman".

In the novel, the protagonist Evelina is a captive at the mercy of people and forces beyond her control. Evelina grows up as the ward of Mr. Villas, a pious reverend who gives Evelina ceaseless instructions even in her absence. Though Evelina is far away from her guardian, she is still influenced by Mr. Villars' persuasion, and to a great extent, she will take his advice as the code of conduct. Mr. Villars knows very well about Evelina's adventure in London through her letters, and soon give his comments and suggestions. Albeit protecting Evelina from potential danger, Mr. Villars' instructions restrict her behavior, always reminding Evelina to hold fast to female virtues. It is hard to assert that Mr. Villars has never had a notion of controlling Evelina regardless of his meticulous custody. In addition, Evelina is constantly influenced by the restraints from other male characters including Captain Mirvan, Sir Clement, Mr. Branghton, etc. Consequently, she should be very scrupulous since most of the men she encounters are captious. However, the individual man's attitude embodies the patriarchal society's repression on women when multiplied together.

Effectual in reshaping women's behavior pattern, conventional restrictions play a significant role in Evelina's maturity. Before her entry into London, she is an innocent girl knowing little about how to behave in social occasions. For lack of social experiences, she makes some jokes in public at the very beginning. It is her innocence and integrity that prevent her from obeying the arrogant men she despises. 
She is somewhat independent and rebellious since she does not hesitate to refuse others, which is considered to be a challenge to the convention. Nevertheless, when Evelina is trapped in a predicament for not observing traditional rules, she begins to reflect on the obstinacy of her true felling, forced to make some changes. After long-term persuasion by others, Evelina pays more attention to her manners for fear that she will become a subject of derision once again. The subsequent experiences demonstrate that Evelina has successively grows into a fair lady by conforming to social conventions.

\section{B. Imperceptible Domestication}

Unlike social conventions that can be perceived in daily life, domestication tends to be an imperceptible process during which women are tamed by the patriarchal rules either actively or passively. Women give in to men's domestication for survival, or they will encounter various forms of violence. It is even pathetic that some will develop identification with those rules unconsciously after long-term domestication. In the novel, Mrs. Mirvan is a quintessentially docile woman who has almost no complaints for her vulgar and violent husband. Her Husband Captain Mirvan is not at home perennially, and hence Mrs. Mirvan has to support the family all along. When Captain Mirvan comes back from sea, he keeps finding fault with his wife rather than expressing care and gratitude for her sacrifice. Captain Mirvan emotionally abuses his wife by "rude jest...and call her a tall, ill-formed thing" [3]. In a letter to Mr. Villars, Evelina shows her sympathy for the poor woman, believing she deserves a better lot. However, it is amazing that Mrs. Mirvan is not angry towards the abusive treatment, and she even ignores her husband's gross behavior. Seeing Madam Duval bullied by Captain Mirvan, Mrs. Mirvan does not urge her husband to stop albeit her sorrow for the old French lady. Mrs. Mirvan cannot do anything to his violent husband for she knows he will never change himself for her.

Functioning as a crutch for misogynistic violence, female docility is the most powerful evidence to show men's effective transformation of women. In most cases, female persuasion is more convincing than male hegemony when it comes to young women's acceptance. It is particularly the case that a mother's marriage has profound influence on her daughter. In the novel, though Evelina's mother is absent, Mrs. Mirvan indeed serves as a matriarchal figure imparting knowledge on female manners to Evelina. Her teaching begins from their trip to London to the end of the story. Mrs. Mirvan takes good care of Evelina, reminding her again and again the importance of chastity. When Evelina makes herself a mockery at the fair, Mrs. Mirvan spares no efforts to share what she knows about being a lady, admonishing some socializing taboos. Obviously, Evelinas eventual metamorphosis is largely attributed to Mrs. Mirvan's relentless guidance.

\section{CONCLUSION}

The paper has explored violence the female characters encounter in Evelina from the physical, psychological and social angles. Violence against women is not sporadic but commonplace across society. It is their conventional role in gender and marriage that has relegated them to such a disadvantaged position where they are unfairly treated by their husband and other males in varied degrees. Such maltreatment includes harm to the body and sexual harassment. Compared with physical violence, however, psychological violence is more difficult to perceive and is more likely to cause irreversible damage. Under the continuous strain of mockeries and curses, women dare not fight back, though, because they have been taught from early childhood to be obedient and not to talk back to men defiantly. Without a proper vent for their pent-up emotions, a host of them have opted to isolate themselves from the outside world, scrupulously guarding their fragile heart from any more traumas. Fundamentally, the $18^{\text {th }}$-century British society was hostile to women, setting enormous rules and regulations against them. As a result, females lost control of their life. More woefully, a large proportion of them were totally "tamed" to be accomplices for the male-chauvinist society, agitating young girls to be willingly reformed by men and finding fault with those female norm-breakers. To sum up, the predicaments of the $18^{\text {th }}$-century British women are disclosed through a detailed analysis of the physical, psychological and social violence against women in Evelina.

\section{REFERENCES}

[1] Chandler, A. "Case Studies in Reading 1: Key Primary Literary Texts." The Eighteenth-Century Literature Handbook, edited by Day, G and Bridget, K, Continuum, 2009, pp. 70-95.

[2] Cutting, R. "Defiant Women: the Growth of Feminism in Fanny Burney's Novels." Studies in English Literature 1500-1900, vol. 17, no. 3, 1978, pp. 519-530.

[3] Burney, F. Evelina, or, A Young Lady's Entrance into the World. Penguin Group, 2012.

[4] Bartky, L. Femininity and domination: Studies in the phenomenology of oppression. Routledge, 1990

[5] Falzon, C. "Freedom and Captivity in Frances Burney's Evelina." Symposia Melitensia, no. 2, 2015, pp. 91-102.

[6] Greenfield, S. "“Oh Dear Resemblance of Thy Murdered Mother': Female Authorship in Evelina." Eighteenth-Century Fiction, vol. 3, no. 4, 1991, pp. 301-320.

[7] Graulich, M. "Violence against Women in Literature of the Western Family." Frontiers: A Journal of Women Studies, vol. 7, no. 3, 1984, pp. 14-20.

[8] Shaffer, J. "Empowering Women in the Marriage Plot." Reading with a Difference: Gender, Race and Cultural Identity, edited by Marotti, A. F. \& Mautner-Wasserman, R. R., Wayne State University Press, 1993.

[9] Staves, S. “'Evelina;' or, Female Difficulties.” Modern Philology, vol. 73 , no. 4, 1976, pp. 368-381. 